\title{
Developing Tools for Community-Based Environmental Education for Migrant Children and Youth in Ghana
}

\author{
Elaine T. Lawson ${ }^{1}$, Christopher Gordon ${ }^{1}$, Adelina Mensah $^{1} \&$ Esinam Atipoe ${ }^{2}$ \\ ${ }^{1}$ Institute for Environment and Sanitation Studies (IESS), University of Ghana, Legon, Ghana \\ ${ }^{2}$ Hanns Seidel Foundation, Kanda, Accra, Ghana \\ Correspondence: Elaine T. Lawson, Institute for Environment and Sanitation Studies (IESS), University of \\ Ghana, P.O. Box LG 209, Legon, Accra, Ghana. E-mail: elaine_t@ug.edu.gh
}

Received: December 15, 2014

Accepted: January 7, 2015

Online Published: May 29, 2015

doi:10.5539/jel.v4n2p6

URL: http://dx.doi.org/10.5539/jel.v4n2p6

\begin{abstract}
This case study presents a detailed description of how community-based environmental education can be used to increase environment awareness and knowledge among migrant children and youth. Data was collected primarily from interviews and learning activities with 454 participants aged 11 to 19 years. The results show that children and youth are aware of environmental problems in their local communities. Environmental problems identified include open defecation, pollution, poor waste management and the use of unsustainable fishing methods. They are also capable of recommending solutions to some of these problems. Solutions recommended include planting more trees, providing waste bins in schools and public places, arresting and prosecuting people who practise open defecation, and public education on the need to stop practices that degrade the environment. The most popular tools recommended for educating children and youth on proper environmental practices and behaviour were dramas and plays. Children and youth thus prefer methods of teaching and communication that are audio-visual, encourage interaction and that keep participants actively involved in the process.
\end{abstract}

Keywords: coastal zone, community-based education, environmental education, Ghana, migration, participation

\section{Introduction}

The concept of environmental education is playing an increasingly vital role in national educational as well as in environmental and conservation strategies (Rickinson, 2001). Environmental education helps to create awareness about the environment and helps people understand their environment better (Aminrad, 2013; Holt \& Barkemeyer, 2012). Athman and Monroe (2000) explain that awareness and knowledge of environmental processes and systems play important roles in behaviour outcome.

Environmental education benefits children and youth cognitively and emotionally (Brown, 2005). It has become an important learning area in early childhood education as well (Pearson \& Degotardi, 2009). Children especially are sensitive to adverse changes in the quality of the environment (Save the Children, 2008). They are also particularly vulnerable to environmental degradation (Braimah \& Lawson, 2014; Moya et al., 2004). Their vulnerability has been attributed to their behaviour as well as their physiology (Briggs, 2003; Jankowska, 2013). Children are believed to go through some psychological sufferings, which are related to worrying about environmental degradation (Lappe \& Perkins, 2004).

This paper presents a study that targeted children and youth in five Anlo-Ewe migrant communities in the coastal zone of Ghana. The coastal zone of Ghana continues to face threats mostly from anthropogenic activities such as over-exploitation of fisheries resources, the use of illegal and unregulated fishing methods, population increase, agriculture, pollution, erosion and sand winning, climate change, invasive species, and transboundary issues (CRC, 2013; GoG, 2010; World Bank, 2010). Young ones are mostly the most impacted and those in migrant communities are often doubly affected. They are often not included in mainstream environmental awareness programmes. They also have to face language and cultural barriers. Hence the main aim of the study was to identify community-based environmental education strategies, which will support such children, increase their environmental knowledge and help them develop positive environmental behaviours. It also provided a platform for them to express themselves in a variety of ways. The results help answer the following questions: 
- What are the most important environmental issues facing coastal communities as perceived by young people and what solutions do they propose?

- What method(s) do children and the youth prefer to use to share environmental information with their peers?

- What are the alternative methods and approaches for community-based environmental education in coastal communities?

This paper contributes to the growing research on community-based environmental education. Its significance lies in the fact that the outcomes of the study were generated through participatory processes that allowed the children and youth to develop approaches that are context specific. As primary stakeholders in the management of the environment, children are often the least consulted (Alderson, 2000, 2001; Kellert, 2005). Yet there is substantial evidence to show that young children are capable of showing concern for their local environment (Barratt Hacking et al., 2007; Barratt et al., 2014; Spencer \& Woolley, 2000).

According to Shepardson et al. (2007) children's understanding of what the environment is shapes the way they conceptualise environmental issues and also their behaviour towards the environment. Hence it is assumed that increased knowledge about the environment will lead to increased awareness and a positive environmental behaviour amongst young ones (Fahlquist, 2008). Madsen (1996) stipulates that awareness is the ultimate driving force that stimulates knowledge. This implies that the more knowledgeable young people are about their environment, the more environmentally aware they will be. He further categorises three levels of awareness, (a) basic belief of an environmental problem, (b) factual and scientific knowledge, and (c) a commitment to solve environmental problems. Behaviour in general is supported by knowledge and attitude but "there is not a direct cause-and-effect progression from knowledge to attitude to behaviour" (Monroe et al., 2000; Wals, 2012).

Considering that environmental education is key for the development of environmental attitudes in the early years, as well as the formation of pro-environmental behaviour in later life (Ballantyne et al., 2006), it is important that all children have the opportunity to benefit from such initiatives (Wilson \& Monroe, 2005; Krasny \& Tidball, 2009; Fiallo \& Jacobson, 1995). However the factors that influence the uptake of environmental knowledge (De Le Vega, 2006) as well as attitudes and behaviour towards natural resources are many (Agrawal, 2007). Hence environmental education approaches must have certain components (Guha \& Chattopadhyay, 2005). For example they should address "locality-specific issues, help to develop individual and necessary skills to solve the environmental problems, enable people to participate in decision-making and evaluating the different strategies for development in terms of social, political, cultural and educational point of view" (Guha \& Chattopadhyay, 2005). Community-based environmental education includes increased community involvement and is designed to match community interests. Activities developed are thus relevant to the local contexts and directly impact the local environment. It helps to strengthen student-community connections and supports children's involvement with issues regarding their local environment.

\section{Methodological Approach}

This paper uses the definition of a child as stated in the Ghana's Children Act, 1998 (Act 560), which is that "a child is a person below the age of eighteen years". In addition the National Youth Policy defines "youths" as "persons who are within the age bracket of fifteen (15) and thirty-five (35)." The research reported in this paper was undertaken in five Ewe migrant communities in the coastal zone of Ghana.

\subsection{Study Communities}

The Ghanaian coastline is $550 \mathrm{~km}$ from the border with Cote d'Ivoire to the border with Togo, and generally covers a low lying area of 30 metres above sea level. The offshore zone in Ghana is about $26,000 \mathrm{~km}$. The coastal zone covers areas in the Western, Central, Greater Accra and Volta regions. There are five target communities selected from each of the five regions (Figure 1).

The snowball non-probability sampling technique was used to select the target communities and to reach the children and youth from the coastal migrant communities. Initial visits were made to all the communities and discussions were held with some local leaders, teachers and young ones in the communities. The study communities were chosen because of the high people-coastal natural resource interactions. In addition they had to be Ewe migrant communities that were not fully integrated into the host communities. Other factors such as community leaders, teachers and other school authorities who were interested in the project as well accessibility of the communities were also taken into account (Table 1). The research team met with local leaders, teachers of schools within the target communities explaining the purpose of the study. 


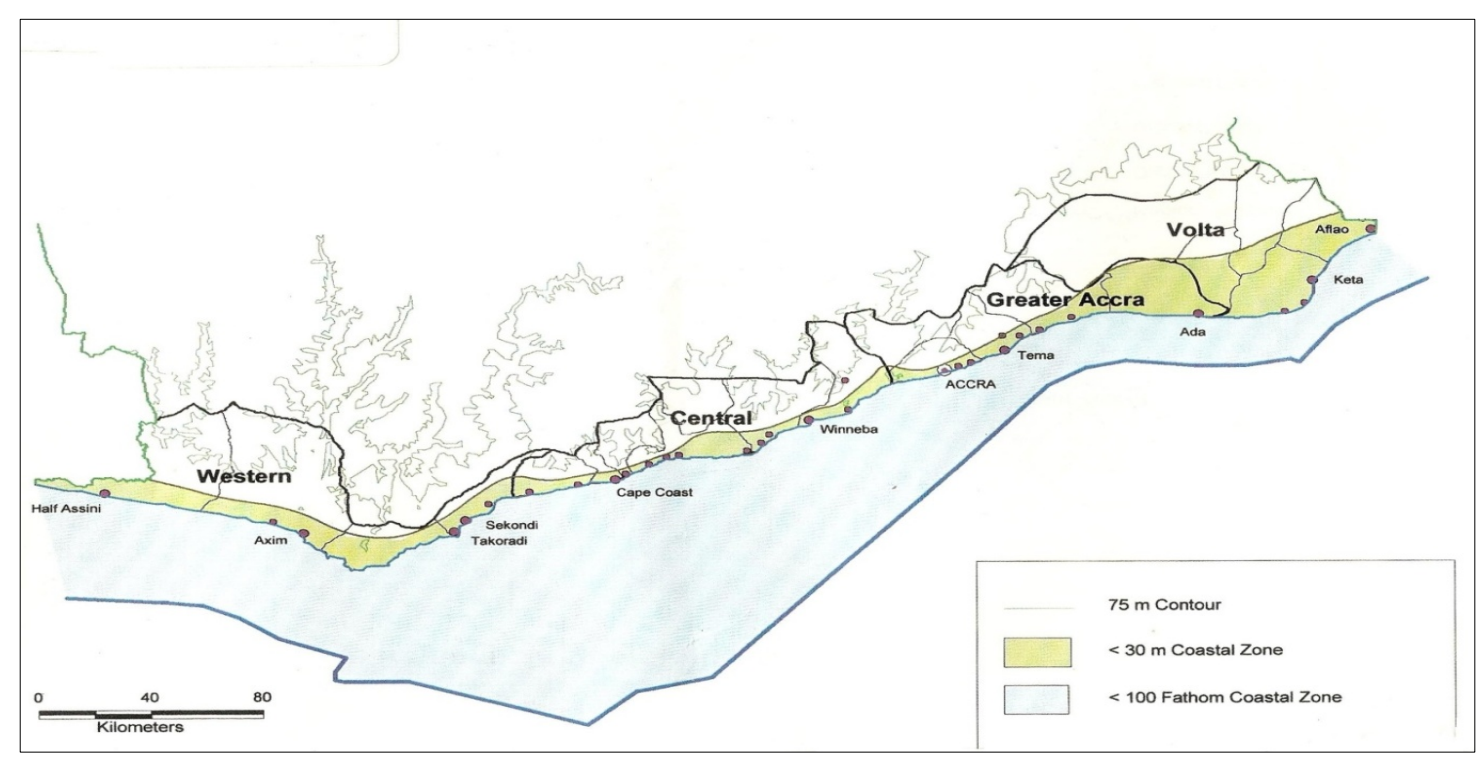

Figure 1. Map of the coastal zone of Ghana

\subsection{Selection of Participants}

In all, 454 participants were selected from schools within the communities with the help of teachers and community facilitators (Table 1). Effort was made to have an equal number and boys and girls participating whilst operating within the confines of a non-probability quota sample. However willingness to participate on the part of the young ones was key.

Table 1. Participating communities and schools

\begin{tabular}{|c|c|c|c|c|}
\hline & Target community & District & Region & Participating schools \\
\hline \multirow[t]{10}{*}{1.} & Akosua Village & Effutu Municipal & Central & Unipra South School \\
\hline & & & & Anglican Primary School \\
\hline & & & & Methodist Primary C/D \\
\hline & & & & Winneba School of Business \\
\hline & & & & Methodist A/B \\
\hline & & & & Methodist Primary A/B \\
\hline & & & & Synclaire International School \\
\hline & & & & Shining Star International School \\
\hline & & & & Methodist B. School \\
\hline & & & & Methodist Primary \\
\hline 2. & Anlo Beach & Shama & Western & Anlo Beach D/A Junior High School \\
\hline 3. & Anyanui & Ketu & Volta & Anyanui L/A Basic School \\
\hline 4. & Duakor & Cape Coast & Central & Archbishop Amissah Memorial Catholic School \\
\hline 5. & Tsokomey & Ga South & Greater Accra & Tsokome M/A Basic School \\
\hline
\end{tabular}

\subsection{Developing Strategies}

\subsubsection{Education}

The children and youth were actively involved in the learning processes, topics and approaches that were developed. Five interactive educational activities were organised, one in each community. At these activities, 
each participant was given two cards of different colours, to list environmental problems in the community on one card and possible solutions to the problems on another. After about twenty to thirty minutes, the cards were collected and the topics for the interactive workshops were selected based on the environmental issues identified. Hence for each community the topics highlighted were based on the environmental issues prioritised by the children and youth. However climate change was added to the list of themes to be discussed in all the communities due to the low awareness among the children and youth. The topics addressed included:

- $\quad$ Erosion and sand winning

- Declining fish catch

- Marine pollution

- Poor sanitation

- Marine debris

- Algal blooms

- Availability of water

- Over exploitation of mangroves

- Climate change

- St. Paul's wilt

2.3.2 Environmental Concerns and Solutions

The participants worked together in groups for about an hour to rank the environmental problems and solutions identified earlier, in order of importance or severity. The final order had to be agreed to by all the members of the group before being finalised.

\subsubsection{Developing Community-Based Environmental Education Strategies}

A key component of the research was developing effective strategies for community-based environmental education that could be replicated in other coastal communities. Since these tools were developed by their peers in similar contexts, the assumption was that they would be easily understood. It also provided a platform for the participants to choose a means of expressing themselves. Since they worked in groups the participants were comfortable discussing their own ideas in a supportive environment.

\subsection{Analyses}

Simple frequencies and cross-tabulations of dependent and independent variables were analysed quantitatively using Statistical Package for the Social Sciences (SPSS) programme version 16. The results were presented in frequency tables showing the raw numbers and in terms of percentages of the total. Descriptive information was also presented in tables.

\section{Results}

\subsection{Background of Respondents}

The highest number of participants came from Duakor followed by Tsokomey (Table 2). The number of active participants was directly related to the levels of engagement of the part of the teachers and community facilitators. This shows that environmental education programmes for children and youth should be carried out with those who work directly with the children, such as teachers and other community leaders to be successful.

Table 2. Selection of participants from the from the study communities

\begin{tabular}{lll}
\hline Community & Frequency & Percent \\
\hline Akosua Village & 62 & 13.7 \\
Anlo Beach & 94 & 20.7 \\
Anyanui & 97 & 21.4 \\
Duakor & 101 & 22.2 \\
Tsokomey & 100 & 22 \\
Total & 454 & 100
\end{tabular}

Note. Sixty-three percent were females as compared to $37 \%$ who were males. The youngest participant was 9 years old and the oldest was 19 years. 


\subsection{Critical Environmental Issues}

Participation is a vital component of community-based environmental education programmes. Hence efforts to develop strategies to help solve coastal degradation should involve key stakeholders. In this study the participants were asked to prioritize environmental problems and to recommend solutions (Barratt et al., 2014). The results indicated that $41 \%$ of them considered open defecation as the most pressing issue. Pollution (of land, water and sea) was important to $27 \%$, and poor waste management to $11 \%$. Unsustainable fishing methods (the use of explosives, chemicals, fishing with light as well as pair trawling), sand winning and deforestation both had the lowest responses (7\%). Tables 3-7 give details of the issues as presented by each community. As much as possible, the original words used by the participants have been maintained, in order to communicate their thoughts. The longest list of environmental issues came from Duakor. Indiscriminate throwing away of rubbish was the most important issue in Akosua Village, and the children and youth believed that environmental education should target this. In both Anyanui and Anlo Beach indiscriminate cutting down of trees including mangroves was the biggest issue. Both communities have vast stretches of mangrove forests, which are also important sources of fuel and income for the communities. Poor sanitation was a problem in Akosua Village, Duakor and Tsokomey. Solutions recommended included planting more trees, provision of bins in public places, arresting people who defecate along the coast and public education

Table 3. Prioritised environmental issues and solutions in Akosua Village

\begin{tabular}{ll}
\hline Environmental issues & Frequency \\
\hline Indiscriminate throwing about of rubbish & 44 \\
Cutting down trees & 27 \\
Open defecation along the coast & 26 \\
Others & 14 \\
Rubbish/bush burning & 12 \\
Using DDT and small sized nets to fish & 11 \\
Soil erosion/flooding & 11 \\
Sand winning/quarrying & 11 \\
Water pollution & 3 \\
Urinating into water bodies & 2 \\
Land degradation & 1 \\
Climate change & 1 \\
Air pollution & 1 \\
Solutions & \\
Stop cutting trees and plant more trees & 27 \\
Stop littering & 22 \\
Provide gutters, dust bins and market facilities & 13 \\
Stop defecating along the coast & 9 \\
Stop sand winning & 9 \\
Stop bush burning & 9 \\
Arrest/fine people involved in activities that degrade the environment & 7 \\
Do not use DDT to fish and use correct mesh-sized nets for fishing & 7 \\
Good sanitation practices & 5 \\
Public education & 1 \\
\hline & \\
& \\
\end{tabular}


Table 4. Prioritised environmental issues and solutions in Anlo Beach

\begin{tabular}{|c|c|}
\hline Environmental issues & Frequency \\
\hline Cutting down trees & 93 \\
\hline Rubbish/bush burning & 73 \\
\hline Air pollution & 68 \\
\hline Sand winning/flooding & 54 \\
\hline Indiscriminate throwing about of rubbish & 51 \\
\hline Water pollution & 50 \\
\hline Over-grazing by animals & 49 \\
\hline Land degradation/pollution & 46 \\
\hline Others & 35 \\
\hline Open defecation along the coast & 31 \\
\hline Urinating/washing into water bodies & 28 \\
\hline Quarrying/construction along water bodies & 15 \\
\hline Soil erosion & 12 \\
\hline Using DDT to fish & 11 \\
\hline Climate change & 10 \\
\hline Improper sanitation practices & 9 \\
\hline \multicolumn{2}{|l|}{ Solutions } \\
\hline Plant more trees & 85 \\
\hline Stop the rampant burning of rubbish and bushes & 73 \\
\hline Stop throwing rubbish about & 50 \\
\hline Arrest/fine people who defecate along the coast & 35 \\
\hline Find food for cattle so they stop over-grazing & 33 \\
\hline Stop sand winning to prevent soil erosion & 31 \\
\hline Others & 25 \\
\hline Avoid water pollution and stop urinating into water bodies & 32 \\
\hline Avoid land pollution & 18 \\
\hline Stop using DDT to fish & 14 \\
\hline Stop washing/bathing in water bodies & 13 \\
\hline Stop quarrying and/or construction/building along the coast & 11 \\
\hline $\begin{array}{l}\text { Encourage proper sanitation practices such as sweeping and cleaning the } \\
\text { environment }\end{array}$ & 9 \\
\hline Public education & 3 \\
\hline Provide gutters, dust bins and market facilities & 2 \\
\hline
\end{tabular}


Table 5. Prioritised environmental issues and solutions in Anyanui

\begin{tabular}{ll}
\hline Environmental issues & Frequency \\
\hline Cutting down trees and mangroves & 50 \\
Open defecation along the coast & 35 \\
Indiscriminate throwing about of rubbish & 19 \\
Others & 17 \\
Sand winning & 14 \\
Urinating into the sea and water bodies & 13 \\
Buildings and constructions along the coast & 13 \\
Catching fish with DDT & 11 \\
Solutions & \\
Stop urinating in water bodies & 12 \\
Stop cutting trees & 11 \\
Stop defecating along the beach & 10 \\
Stop throwing rubbish about & 10 \\
Clean gutters everyday & 6 \\
Stop using DDT to fish & 5 \\
Stop sand winning & 5 \\
Report offenders who destroy the environment to the police & 4 \\
Plant more trees & 4 \\
Stop washing in rivers & 3 \\
Laws should be passed to arrest offenders & 2 \\
Stop building houses along the coast & 2 \\
Clean houses and surroundings & 1 \\
Public education & 1 \\
Stop road constructions near the beaches & \\
Stop playing at the sea shore & \\
\hline & 1 \\
\hline
\end{tabular}

Table 6. Prioritised environmental issues and solutions in Duakor

\begin{tabular}{ll}
\hline Environmental issues & Frequency \\
\hline Indiscriminate throwing of rubbish and pouring water into gutters & 62 \\
Water pollution (such as bathing and washing in water bodies) & 49 \\
Air pollution and bush burning & 49 \\
Indiscriminate cutting of trees & 33 \\
Land pollution & 30 \\
Defecation along the coast & 18 \\
Using chemicals like DDT to fish & 9 \\
Over-grazing by livestock & 5 \\
Others & 4 \\
Improper mining activities & 3 \\
\hline
\end{tabular}


Poor sanitation practices

Land degradation

Sand winning and coastal erosion

\section{Solutions}

Putting dust bins in schools and communities

Stop indiscriminate cutting of trees

Stop defecation and selling along on the beach

Proper waste disposal

Planting more trees

Stop bush burning in the homes and beaches

Stop urinating, bathing and washing in water bodies

We must clean our rooms and compounds

Stop using DDT to fish

Find other sources of food for the cattle to stop them from 9

Stop smoking in public

Washing our clothes and bathing regularly (personal hygiene)

Stop sand winning 37 22 21

15 14

13

11

10

9

8

2

2

2

5

1

Table 7. Prioritised environmental issues and solutions in Tsokomey

\begin{tabular}{ll}
\hline Environmental issues & Frequency \\
\hline Indiscriminate throwing about of rubbish & 67 \\
Open defecation along the coast & 48 \\
Water pollution from urinating and washing into water bodies & 28 \\
Cutting down trees & 27 \\
Air pollution & 20 \\
Land degradation / land pollution & 12 \\
Poor sanitation and hygiene practices & 12 \\
Sand winning and flooding & 10 \\
Soil erosion & 7 \\
Climate change & 5 \\
Using small-sized nets and DDT to fish & 4 \\
Over-grazing by animals & 2 \\
Building along water bodies & 1 \\
Solutions & \\
Stop the indiscriminate throwing about of rubbish & 62 \\
Plant more trees and stop cutting down trees & 38 \\
Stop defecating along the coast & 37 \\
Arrest/fine people who win sand, on beaches & 20 \\
Stop washing, bathing and urinating in water bodies & 16 \\
Proper sanitation practices and personal hygiene & 16 \\
\hline
\end{tabular}




\begin{tabular}{ll}
\hline Law enforcement agencies must protect the beaches & 6 \\
Using large sized nets to fish and not using DDT to fish & 4 \\
Avoid water pollution & 4 \\
Provision of gutters, dust bins and market facilities & 4 \\
Stop air pollution (rubbish/bush burning) & 3 \\
Others & 2 \\
Public education & 1 \\
Avoid land pollution/degradation & 1 \\
\hline
\end{tabular}

\subsection{Preferred Tools for Sharing Environmental Information}

About $69 \%$ of participants preferred to communicate environmental issues through drama or singing and dancing. Other means of communication were poetry, drawing and drumming (Figure 2).

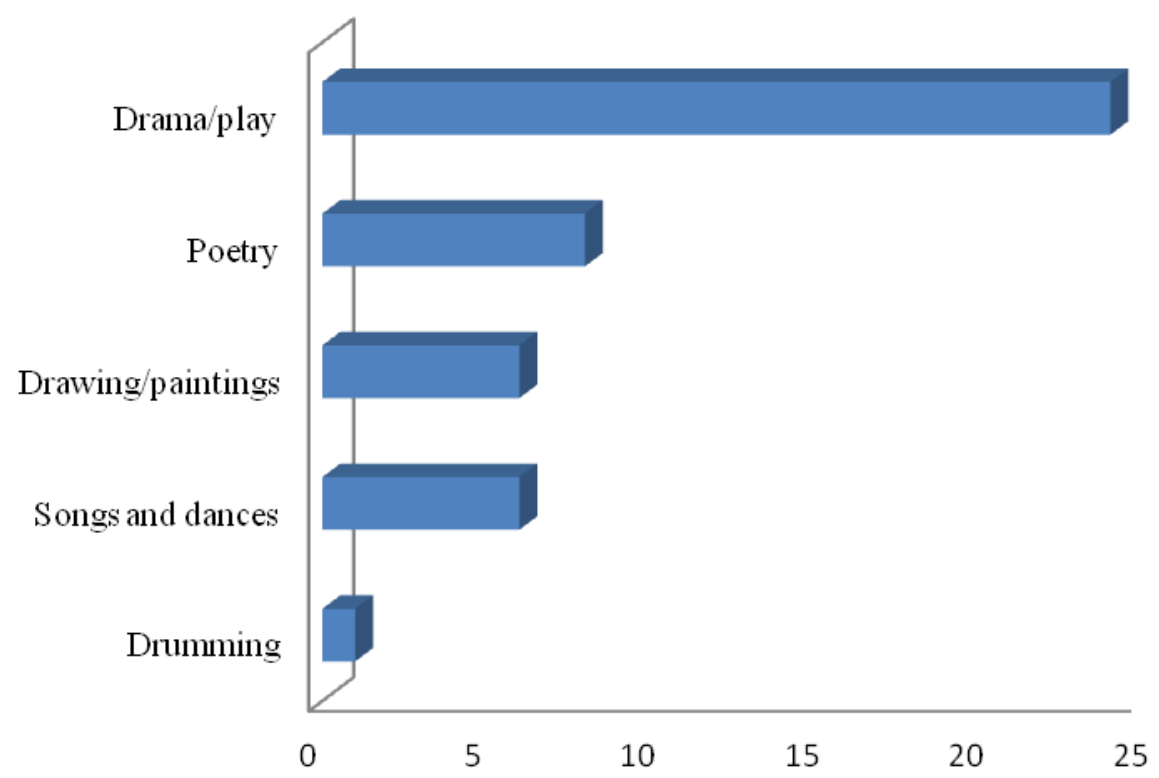

Figure 2. Preferred methods of communicating environmental issues

This shows that the ideal tools for sharing information are audio-visual tools. The content should be grounded in issues of local interests (Howley et al., 2011).

\section{Discussion}

The communities selected for the study were all low-income migrant communities with children having little or poor access to basic amenities such as electricity, safe drinking water and good housing. Children here also have relatively few career guidance programmes and role models as compared to their peers in many urban areas. Absenteeism is also high as young boys have to help their male relatives to fish and young girls have to do house chores and also engage in petty trading (Kagoda, 2012). Interactive methods of teaching such as the use of electronic audiovisuals often face challenges in these environments.

This project sought to identify new and effective approaches that can be used in community-based environmental education, especially for children and youth in coastal communities in Ghana. The participants were all in school and most of their knowledge on environmental issues was from their school curricular. The results have shown that children and youth are aware of their local environment and show concern over the state of their local environment (R. Barratt \& Barratt, 2014; Spencer \& Woolley, 2000). In all communities participants were able to mention environmental problems that needed to be addressed immediately. However their awareness on 
global environmental issues was less. Lessons learnt also include the need to use what children and youth are familiar with to teach them about issues they have little knowledge of or may even consider abstract.

The use of plays was seen by participants as the most effective way of communicating environmental issues to their peers. This was followed by poetry. This means that children and young ones prefer methods of teaching and communications that are audio-visual, encourage interaction and that keep participants involved. This highlights the need for alternative approaches, which are more flexible and innovative, and can take place outside the classroom setting. Bringing children and youth closer to their natural environment creates in them a commitment to conservation practices, desire to learn about nature, personal well-being, self-confidence, and initiative (Kellert, 1998). The use of multiple visual aids such as posters and flyers helped the participants at the interactive meetings to relate otherwise abstract issues to their own setting. Interactive activities can also impact on children's oral and written language development (Yaden et al., 2000).

Local languages as medium of instruction could also help participants reach other out of school children as well as community members. Interestingly whilst public education was mentioned in almost all the communities it was not seen as an important means of solving environmental problems within the community. Rather priority was given to measures that would lead to the enforcement of existing laws. Many of the participants used the words such as "stop", "arrest" and "fine". Whilst Ghana has enacted a number of laws aimed at protecting the environment, enforcement of these laws has been a great challenge. This fact has been reiterated on many platforms.

Building relationships between the school and its local community through the engagement of local community leaders and law enforcement agencies is important for the sustainability and success of environmental initiatives. Engaging key stakeholders in the community at the very beginning helps build relationships between the school and its local community, and also between students and their peers.

The objectives of project fitted that of the Tbilisi Declaration for environmental education (UNESCO, 1978; Thomson \& Hoffman, 2003), namely;

- Awareness: to help social groups and individuals acquire an awareness and sensitivity to the total environment and its allied problems.

- Knowledge: to help social groups and individuals gain a variety of experience in, and acquire a basic understanding of, the environment and its associated problems.

- Attitudes: to help social groups and individuals acquire a set of values and feelings of concern for the environment and the motivation for actively participating in environmental improvement and protection.

- Skills: to help social groups and individuals acquire the skills for identifying and solving environmental problems.

- Participation: to provide social groups and individuals with an opportunity to be actively involved at all levels in working toward resolution of environmental problems.

The presence of community leaders, facilitators and teachers were identified as crucial to the success of the community-based education initiatives. In communities that lacked these, the levels of interest among the children and youth was low (Wither, 2001).

\section{Conclusions}

The study concluded that the children and youth have some awareness of the environmental issues in their communities, these issues are common, and that they generally prefer more active and interactive means of sharing environmental information with their peers. This information is important for community-based environmental education in Ghana. This is especially true of populations which are already at risk from environmental degradation. To address coastal issues nationally, three key policy objectives have been identified in the development agenda of Ghana (GoG, 2010). These are:

- Investing directly for development.

- Promoting regulatory or economic incentives and improving institutional/policy reforms.

- Increasing knowledge and awareness of decision-makers or resource users, for more appropriate management.

However engagement and action at the local level are lacking. As key stakeholders, more innovative ways must be used to communicate environmental issues with children and youth. The study identified drama and plays, poetry, paintings and songs as key tools in community-based environmental education. More effort should be made to communicate with the communities by creating platforms where the children and youth can share their plays and songs with the aim of engaging communities on environmental issues. Much emphasis must be laid on 
excursions,outdoor and experiential programs. The capacities of teachers and community leaders need to be built to appreciate some of these innovative methods of environmental education such as play-based learning.

A critical issue that came out during the course of the project was the need to communicate with a number of stakeholders, which include children and youth who are out of school and who communicate largely in their mother tongue. As of 2012, 58 million children of primary school age and another 63 million children of lower secondary school age were still out of school (UNESCO, 2014; UIS, 2011). Whilst research confirms that children learn best in their mother tongue as a prelude to and complement of bilingual and multilingual education (Ball, 2011), special tools of communication to reach these ones are also needed.

\section{Acknowledgements}

This study was undertaken with support from Hanns Seidel Foundation, Ghana and the Institute for Environment and Sanitation Studies, University of Ghana.

\section{References}

Alderson, P. (2000). Children as researchers: The effects of participation rights on research methodology. In P. Christensen, \& A. James (Eds.), Research with children (pp. 241-257). London: Falmer Press.

Alderson, P. (2001). Research by children. International Journal of Social Research Methodology, 4(2), 139-153. http://dx.doi.org/10.1080/136455701750158903

Aminrad, Z., Zakariya, Z. B. S., Binti, S., Hadi, A. S., \& Sakari, M. (2013). Relationship between awareness, knowledge and attitudes towards environmental education among secondary school students in Malaysia. World Applied Sciences Journal, 22 (9), 1326-1333. http://dx.doi.org/10.5829/idosi.wasj.2013.22.09.275

Athman, J., \& Monroe, M. (2000). Elements of effective environmental education programs. Retrieved from http://www.rbff.org/educational/reports.cfm

Ball, J. (2011). Enhancing learning of children from diverse language backgrounds: mother tongue-based bilingual or multilingual education in the early years (Paper commissioned for UNESCO). Retrieved from http://unesdoc.unesco.org/images/0021/002122/212270e.pdf

Barratt, H. E., Barratt, R., \& Scott, W. (2007). Engaging children: Research issues around participation and environmental learning. Environmental Education Research, 13(4), 529-544. http://dx.doi.org/10.1080/ 13504620701600271

Barratt, R., Barratt, H. E., \& Pat, B. (2014). Innovative Approaches to Early Childhood Education for Sustainability case studies from the field. In J. Davis, \& S. Elliot (Eds.), Research in early childhood education for sustainability: International perspectives and provocations (pp. 225-247). UK: Routledge.

Ballantyne, R., Fien, J., \& Packer, J. (2001). Program effectiveness in facilitating intergenerational influence in environmental education: Lessons from the field. Journal of Environmental Education, 32(4), 8-15. http://dx.doi.org/10.1080/00958960109598657

Braimah, F. R., \& Lawson, E. T. (2014). Does is matter where I live? Comparing the impact of housing quality on child development in slum and non-slum areas in Ghana. International Journal of Child, Youth and Family Studies, 5(3), 375-393.

Briggs, D. (2003). Making a difference: Indicators to improve children's environmental health. World Health Organization. Retrieved from http://www.who.int/phe/children/en/cehindicsum.pdf

Brown, S. (2005). Handbook for Environmental Education in the General Education Classroom: A Resource Designed for Educators in Maryland. St. Mary's College of Maryland, St. Mary's City, Maryland.

Coastal Resources Center. (2013). Solving the fisheries crisis in Ghana: A fresh approach to collaborative fisheries management. USAID-URI Integrated Coastal and Fisheries Governance (ICFG) Initiative, Coastal Resources Center, Graduate School of Oceanography, University of Rhode Island.

De Le Vega, E. (2006). A preliminary evaluation of awareness, knowledge and attitude in environmental education specialist, instructors, students and parents in Southwest Florida (Doctoral dissertation). Florida Gulf Coast University, Fort Myers FL, USA.

Fahlquist, J. N. (2008). Moral responsibility for environmental problems-Individual or institutional? Journal of Agricultural Environmental Ethics, 22, 109-124. http://dx.doi.org/10.1007/s10806-008-9134-5 
Fiallo, E., \& Jacobson, S. (1995). Local communities and protected areas: Attitudes of rural residents towards conservation and Machalilla National Park, Ecuador. Environmental Conservation, 22, 241-249. http://dx.doi.org/10.1017/S037689290001064X

Fussell, A. (2008). Benefits of environmental education: Fourth graders' attitudes towards the environment. $A$ Rising Tide, 1. Retrieved from http://www.smcm.edu/educationstudies/pdf/rising-tide/volume-1/ VOL1-article3.pdf

Government of Ghana. (2011). Ghana Second Communication to the UNFCCC. Environmental Protection Agency. Accra.

Guha, M., \& Chattopadhyay, A. (2005). Environmental education: A pathway for sustainable development IIPS Mumbai. ENVIS center, 2(4). Retrieved from http://www.iipsenvis.nic.in/Newsletters/vol2no4/ Enviro_Education.htm

Hill, C. (1998). Conflicting attitudes towards elephants around the Budongo Forest Reserve, Uganda. Environmental Conservation, 25(3), 244-250. http://dx.doi.org/10.1017/S0376892998000307

Holt, D., \& Barkemeyer, R. (2012). Media coverage of sustainable development issues-attention cycles or punctuated equilibrium? Sustainable Development, 20, 1-17. http://dx.doi.org/10.1002/sd.460

Hopkins, C., Damlamian, J., \& López, O. G. (1996). Evolving towards education for sustainable development: An international perspective. Nature \& Resources, 32(3), 2-11.

Howley, A., Howley, M., Camper, C., \& Perko, H. (2011). Place-based education at Island Community School. The Journal of Environmental Education, 42(4), 216-236. http://dx.doi.org/10.1080/00958964.2011.556682

Jankowska, M. M. (2013). Santa Barbara, integrating space and place into children's perceptions of environmental health hazards in Accra, Ghana (Doctoral dissertation). San Diego State University and University of California. Santa Barbara. Retrieved from http://alexandria.ucsb.edu/lib/ark:/48907/f3zc80zv

Kellert, S. R. (1998). A national study of outdoor wilderness experience (Unpublished report). Yale University, School of Forestry and Environmental Studies.

Krasny, M. E., \& Tidball, K. G. (2009). Applying a resilience systems framework to urban environmental education. Environmental Education Research, 15, 465-482. http://dx.doi.org10.1080/13504620903003290

Lappe, F. M., \& Perkins, J. (2004). You have the power: Choosing courage in a culture of fear. New York, NY: Tarcher/Putnam.

Lawson, E. T., \& Bentil, G. (2014). Shifting sands: Changes in community perceptions of mining in Ghana. Journal of Environment, Development and Sustainability, 16(1), 217-238. http://dx.doi.org/10.1007/ s10668-013-9472-y

Kagoda, A. M. (2012). Addressing inequalities the heart of the post-2015 development agenda and the future we want for all global thematic consultation access to quality primary education in rural societies of Uganda. Retrieved from http://www.worldwewant2015.org/file/290351/download/314755

Madsen, P. (1996). What can universities and professional schools do to save the environment? In J. B. Callicott, \& F. J. Rocha (Eds.), Earth Summit Ethics: Toward a reconstructive postmodern philosophy of environmental education (pp. 493-502). New York: Albany State University of New York Press.

Mehta, J., \& Heinen, J. (2001). Does community-based conservation shape favorable attitudes among locals? An empirical study from Nepal. Environmental Management, 8(2), 165-177. http://dx.doi.org/10.1007/ s002670010215

Monroe, M., Day, B., \& Grieser, M. (2000). GreenCOM weaves four strands. In B. Day, \& M. Monroe (Eds.), Environmental education and communication for a sustainable world-Handbook for international practitioners (pp. 3-6). Washington, DC: Academy for Educational Development.

Moya, J., Bearer, C., \& Etzel, R. (2004). Children's behavior and physiology and how it affects exposure to environmental contaminants. Pediatrics, 113(4), 996-1006. http://dx.doi.org/10.1542/peds.113.4.S1.996

Pearson, E., \& Degotardi, S. (2009). Education for sustainable development in early childhood education: A global solution to local concerns. International Journal of Early Childhood, 419, 97-111. http://dx.doi.org/ 10.1007/BF03168881

Shepardson, D., Wee, B., Priddy, M., \& Harbor, J. (2007). Students' mental models of the environment. Journal of Research in Science Teaching, 44(2), 327-348. http://dx.doi.org/10.1002/tea.20161 
Rickinson, M. (2001). Learners and learning in environmental education: A critical review of the evidence. Environmental Education Research, 7(3), 207-320. http://dx.doi.org/10.1080/13504620120065230

Save the Children. (2008). Legacy of disasters: The impact of climate change on children. Save the Children UK, London. Retrieved from http://www.childreninachangingclimate.org/legacy_of_disasters.pdf

Spencer, C., \& Woolley, H. (2000). Children and the city: A summary of recent environmental psychology research. Child: Care, Health and Environment, 28(3), 181-198. http://dx.doi.org/10.1046/ j.1365-2214.2000.00125.x

Thomson, G., \& Hoffman, J. (2003). Measuring the success of environmental education programs. Canadian Parks and Wilderness Society, and Sierra Club of Canada. Retrieved from http://macaw.pbworks.com/f/ measuring_ee_outcomes.pdf

UNESCO Institute for Statistics (UIS). (2011). Out-of-school children: New data reveal persistent challenges UIS Fact Sheet. Retrieved from http://www.uis.unesco.org/FactSheets/Documents/FS12_2011_OOSC_ EN.pdf

UNESCO. (1978). Final Report: Intergovernmental Conference on Environmental Education. Organized by UNESCO in cooperation with UNEP, Tbilisi, USSR, 14-26 October 1977, Paris: UNESCO.

UNESCO. (2014). Progress in getting all children to school stalls, but some countries show the way forward Policy Paper. Retrieved from http://www.uis.unesco.org/Education/Documents/fs-28-out-of-schoolchildren-en.pdf

United States Environmental Protection Agency. (1998). An EPA/USDA Partnership to Support Community-Based Education: Discussion Paper, Office of External Affairs. Retrieved from http://www.uwex.edu/erc/doc/discussion_paper.pdf

Wals, A. E. J. (2012). Learning our way out of unsustainability: The role of environmental education. In S. D. Clayton (Ed.), The Oxford Handbook of Environmental and Conservation Psychology (pp. 328-663). Oxford: Oxford University Press. http://dx.doi.org/10.1093/oxfordhb/9780199733026.013.0032

Wilson, J. R., \& Monroe, M. C. (2005). Biodiversity curriculum that supports education reform. Applied Environmental Education and Communication, 4(2), 125-138. http://dx.doi.org/10.1080/ 15330150590934552

World Bank. (2010). Economics of adaptation to climate change: social synthesis report. The International Bank for Reconstruction and Development.

Yaden, D. B., Rowe, D. W., \& MacGillivray, L. (2000). Emergent literacy: A matter of perspectives. In M. L. Kamil, P. B. Mosenthal, P. D. Pearson, \& R. Barr (Eds.), Handbook of reading research (pp. 254-425). Mahwah, NJ: Lawrence Erlbaum.

\section{Copyrights}

Copyright for this article is retained by the author(s), with first publication rights granted to the journal.

This is an open-access article distributed under the terms and conditions of the Creative Commons Attribution license (http://creativecommons.org/licenses/by/3.0/). 